\title{
A MEROVINGIAN SURPRISE: EARLY MEDIEVAL RADIOCARBON DATES ON CREMATED BONE (BORSBEEK, BELGIUM)
}

\author{
Guy De Mulder ${ }^{1,2} \cdot$ Mark Van Strydonck $^{3} \cdot$ Rica Annaert $^{4} \cdot$ Mathieu Boudin ${ }^{3}$
}

\begin{abstract}
Radiocarbon dating of cremated bone is a well-established practice in the study of prehistoric cremation cemeteries since the introduction of the method in the late $1990 \mathrm{~s} .{ }^{14} \mathrm{C}$ dates on the Late Bronze Age urnfield and Merovingian cemetery at Borsbeek in Belgium shed new light on Merovingian funerary practices. Inhumation was the dominant funerary rite in this period in the Austrasian region. In the Scheldt Valley, however, some cremations are known, termed Brandgrubengräber, which consist of the deposition of a mix of cremated bone and the remnants from the pyre in the grave pit. ${ }^{14} \mathrm{C}$ dates from Borsbeek show that other ways of deposition of cremated bone in this period existed. In both cases, bones were selected from the pyre and wrapped in an organic container before being buried. Recent excavation and ${ }^{14} \mathrm{C}$ dates from another Merovingian cemetery at Broechem confirmed the information about the burial rites and chronology from Borsbeek. This early Medieval practice of cremation rituals seems an indication of new arrivals of colonists from northern regions where cremation remained the dominant funerary rite. Another case at Borsbeek shows the reuse of a Late Bronze Age urn in the Merovingian period. This practice is known from Viking burials in Scandinavia, but was not ascertained until now in Flanders.
\end{abstract}

\section{INTRODUCTION}

In August 1965, 3 amateur archaeologists discovered a Late Bronze Age-Early Iron Age urnfield and a Merovingian cemetery at the village of Borsbeek while studying a site where a new plant was constructed in the region of Antwerp (Belgium) (Figure 1). The site was excavated under difficult conditions by the amateur archaeologists. An extensive excavation was beyond the abilities of the discoverers, but the areas where archaeological features were ascertained were excavated. The "rich" character of some cremation graves quickly attracted the attention of professional archaeologists. A first publication of some Late Bronze Age graves followed soon thereafter (Desittere and Goossens 1966). In 1966, the southern sector of the site was further excavated by the former National Archaeological Service (Nationale Dienst voor Opgravingen). This excavation was only concentrated on the Merovingian part of the funerary site. The results of these 2 archaeological campaigns were presented in 2 different excavation reports. The first report was reserved for the Merovingian finds. Forty-five Merovingian inhumations were found, and also a single cremation that could be identified as Merovingian due to the funerary objects in this grave. This cemetery was dated by typochronological study of the burial goods to the 7th century $\mathrm{AD}$, except for 1 grave that could date to the 6th century AD (De Boe 1970).

A second report concentrated on the urnfield cemetery, with an estimated 22 cremation graves discovered. One of these was rather doubtful due to the bad preservation of the feature. A recent revision of the field notes by A Goossens revealed the existence of an unknown cremation grave that was not published in 1972. The graves were dated to the Late Bronze Age and Early Iron Age based on typochronological study of the grave finds. A few other features were identified as rubbish pits dating from the early phase of the Late Iron Age (Van Impe 1972).

\footnotetext{
${ }^{1}$ Department of Archaeology, Ghent University, Sint-Pietersnieuwstraat 35, B-9000 Ghent, Belgium.

2Corresponding author. Email: Guy.DeMulder@UGent.be.

${ }^{3}$ Royal Institute for Cultural Heritage, Jubelpark 1, B-1000 Brussels, Belgium.

${ }^{4}$ Flemish Heritage Institute, Phoenix-gebouw, Koning Albert II-laan 19, bus 5, B-1210 Brussels, Belgium.
}

(C) 2012 by the Arizona Board of Regents on behalf of the University of Arizona Proceedings of the 6th International Radiocarbon and Archaeology Symposium, edited by E Boaretto and N R Rebollo Franco RADIOCARBON, $\mathrm{Vol} 54, \mathrm{Nr} 3-4,2012$, p 581-588 


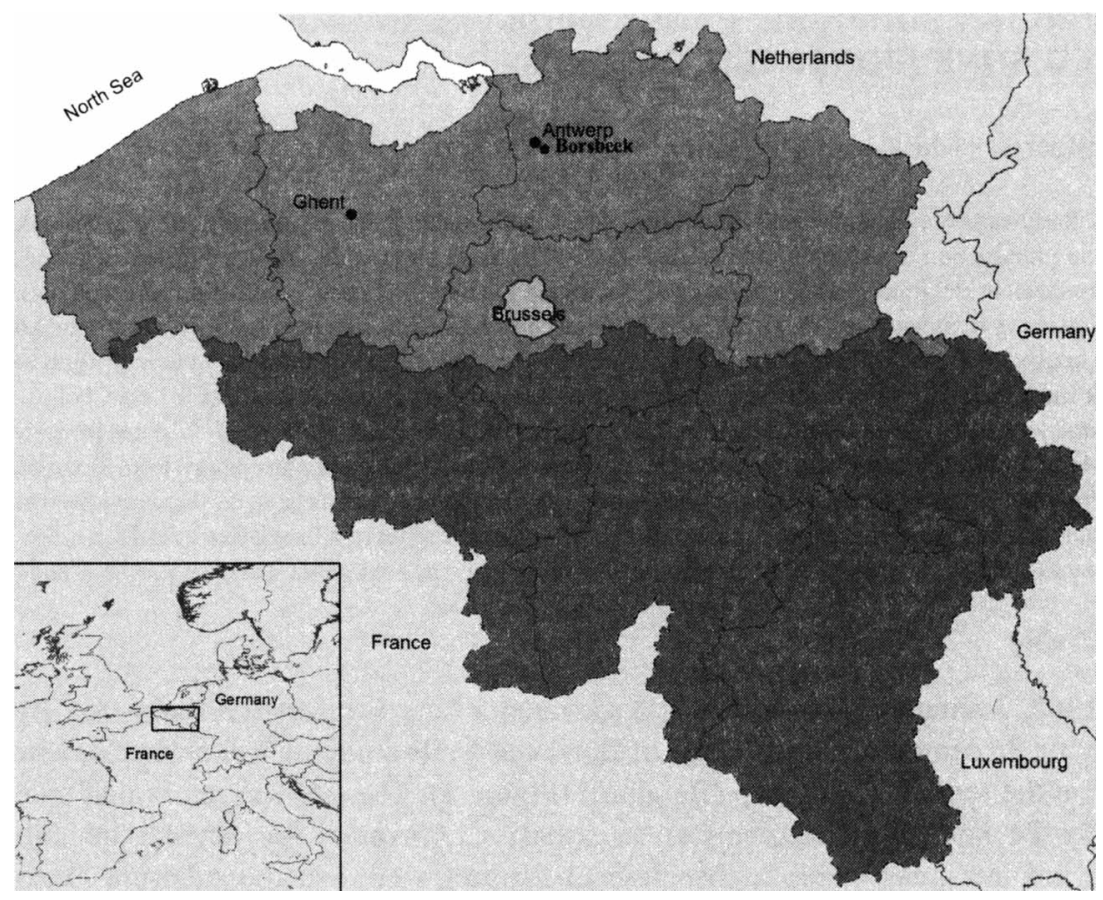

Figure 1 Location of the Borsbeek site

\section{Dating of Cremated Bones}

Radiocarbon dating of cremated bone is a well-established practice in the study of prehistoric cremation cemeteries since the introduction of the method in the late 1990s (Lanting et al. 2001; Lanting and van der Plicht 2001/2002; Van Strydonck et al. 2005; De Mulder et al. 2007). During a research project on ${ }^{14} \mathrm{C}$ dating of Late Bronze Age and Early Iron Age cemeteries in the Scheldt Basin, a series of cremated bone samples were selected from the urnfield cemetery at Borsbeek, both from the urngraves (type I) as well as from the so-called "bonepackgraves" (bone selected from the pyre and wrapped in an organic container such as a piece of cloth or leather; also known by the German term Knochenlager) (type II), and a so-called Brandgrubengrab, which can be described as a funerary pit containing a mixture of cremated bones, charcoal fragments from the pyre, and possibly also burned fragments of grave goods (type III). The material was selected from the cremated bone preserved in the private collection by A Goossens and the local historical-archaeological museum Die Swaene at Heist-op-den-Berg. This selection was made according to the standards for selecting cremated bones as described in Van Strydonck et al. (2009a). No charcoal samples were selected for dating as there was almost no charcoal preserved from the rescue-excavation.

\section{MATERIAL AND METHODS}

Eleven cremation graves were dated on cremated bone. After a sample quality test (Van Strydonck et al. 2009b), the bones were dated by accelerator mass spectrometry (AMS) using standard procedures for the preparation of cremated bone samples. Material from two of the graves were dated twice: grave 1 as a test for the laboratory procedures of the Brussels laboratory and grave 4 to confirm the first measurement of the ${ }^{14} \mathrm{C}$ date again (Table 1). 
Table $1{ }^{14} \mathrm{C}$ results on cremated bone from Borsbeek cremation graves.

\begin{tabular}{|c|c|c|c|c|}
\hline Grave \# & Type & Lab nr & $\begin{array}{l}\text { Conventional }{ }^{14} \mathrm{C} \text { age } \\
\text { (yr BP) }\end{array}$ & Calibrated date $(2 \sigma)$ \\
\hline 1 & I & KIA-37896 & $2865 \pm 35$ & $\begin{array}{l}1160(1.1 \%) 1140 \mathrm{BC} \\
1130(94.3 \%) 920 \mathrm{BC}\end{array}$ \\
\hline & & KIA-38428 & $2855 \pm 30$ & $1130(95.4 \%) 920 \mathrm{BC}$ \\
\hline 2 & II? & KIA-37916 & $2670 \pm 35$ & $900(95.4 \%) 790 \mathrm{BC}$ \\
\hline 3 & I & KIA-37919 & $2805 \pm 35$ & $\begin{array}{r}1050(90.5 \%) 890 \mathrm{BC} \\
880(4.9 \%) 840 \mathrm{BC}\end{array}$ \\
\hline 4 & I & $\begin{array}{l}\text { KIA-37917 } \\
\text { KIA-40552 }\end{array}$ & $\begin{array}{l}1460 \pm 35 \\
1465 \pm 30\end{array}$ & $\begin{array}{l}\text { AD } 540(95.4 \%) 650 \\
\text { AD } 550(95.4 \%) 650\end{array}$ \\
\hline 5 & I & KIA-37897 & $2895 \pm 40$ & $\begin{array}{c}1260(1.7 \%) 1230 \mathrm{BC} \\
1220(92.0 \%) 970 \mathrm{BC} \\
960(1.7 \%) 940 \mathrm{BC}\end{array}$ \\
\hline 6 & I & KIA-37898 & $2825 \pm 30$ & $1090(95.4 \%) 900 \mathrm{BC}$ \\
\hline 7 & I & KIA-37920 & $2825 \pm 40$ & $1120(95.4 \%) 890 \mathrm{BC}$ \\
\hline 8 & I & KIA-37903 & $2865 \pm 35$ & $\begin{array}{l}1160(1.1 \%) 1140 \mathrm{BC} \\
1130(94.3 \%) 920 \mathrm{BC}\end{array}$ \\
\hline 12 & II & KIA-37904 & $1520 \pm 30$ & AD $430(95.4 \%) 610$ \\
\hline 14 & II & KIA-37905 & $1580 \pm 30$ & AD $410(95.4 \%) 550$ \\
\hline 26 & III & KIA-37921 & $2595 \pm 40$ & $\begin{array}{l}840(76.3 \%) 740 \mathrm{BC} \\
690(8.5 \%) 660 \mathrm{BC} \\
650(10.6 \%) 550 \mathrm{BC}\end{array}$ \\
\hline
\end{tabular}

Both dates for grave 1 show a chronological agreement and are combined using OxCal R_combine: $2859 \pm 23$ BP (1120 (95.4\%) $930 \mathrm{BC})\left[\chi^{2}\right.$ test: $\left.\left.d f=1 ; t=0.0(5 \% 3.8)\right]\right]$. The same agreement was ascertained for grave 4. The combined results using OxCal R_Combine: $1463 \pm 23$ BP (AD 555 (95.4\%) 645) [ $\chi^{2}$ test: $\left.d f=1 ; t=0.0(5 \% 3.8)\right]$ (OxCal v 3.10, Bronk Ramsey 1995, 2001; using IntCal09 calibration data, Reimer et al. 2009).

Eight dates were obtained for the urnfield cemetery (graves 1, 2, 3, 5, 6, 7, 8, and 26(G)). Seven of these dates belonged to the Late Bronze Age and 1 cremation grave was dated to the Early Iron Age. An additional $3{ }^{14} \mathrm{C}$ results, however, were significantly younger and indicate an early Medieval age, which we distinguish as a Merovingian period cemetery. These Merovingian period dates were obtained on 2 bonepackgraves (graves 12 and 14) and 1 urngrave (grave 4). The results help shed new light on the Merovingian funerary practices in Belgium (Figure 2).

\section{DISCUSSION}

\section{A. Urnfield Cemetery}

The chronology of the urnfield cemetery was proven by $8{ }^{14} \mathrm{C}$ dates (graves $1-3,5-8$, and 26; see Table 1, Figure 2), which were mostly obtained from urngraves except from 1 bonepackgrave and a Brandgrubengrab. These dates fall in the Late Bronze Age except for the result on the Brandgrubengrab, which was younger and situated at the end of the Late Bronze Age-Early Iron Age. The calibration curve situates this grave rather to the Late Bronze Age-Early Iron Age transition.

According to the interquartile range (IQR), the occupation of the urnfield cemetery has to be situated between 1163 and 684 cal $\mathrm{BC}$, with a mean probability between 1036 and 886 cal $\mathrm{BC}$ (Figure 3). The oldest dates (KIA-37917: $2895 \pm 40$ BP and KIA-37896: $2865 \pm 35$ BP) indicate that the urnfield cemetery at Borsbeek started already before $1100 \mathrm{BC}$. This possible earlier start of the 


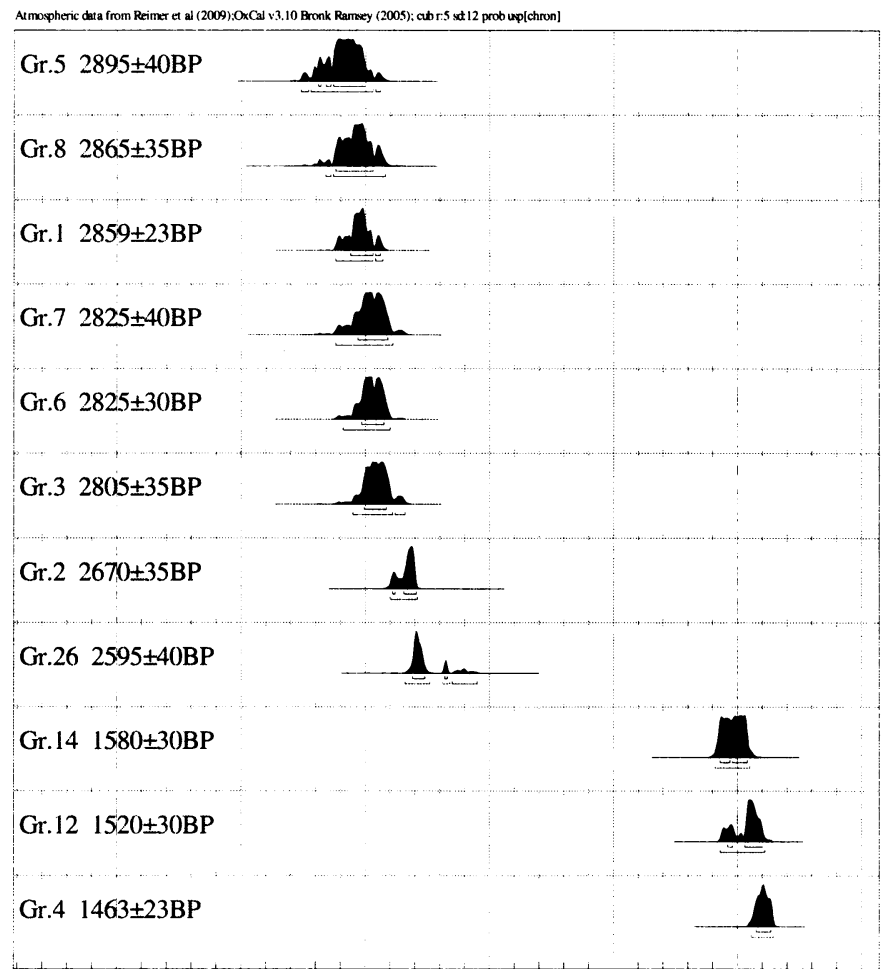

2000CalBC 1500CalBC 1000CalBC 500CalBCCalBC/CalAD500CalAD 1000CalAD

Calibrated date

Figure 2 Calibrated ${ }^{14} \mathrm{C}$ dates from Borsbeek cremation graves

urnfield cemeteries with a date before $1100 \mathrm{BC}$ has also been reported for the urnfields of Velzeke/ Paddestraat and Blicquy in western Belgium (De Mulder et al. 2007). Another recent ${ }^{14} \mathrm{C}$ date for the urnfield cemetery at Aalter/Oostergem (KIA-40864: $3060 \pm 20$ BP; see http://c14.kikirpa.be/ search.php) is also available, further indicating an earlier start than previously believed for these type of burials.

\section{B. Merovingian Cemetery}

In the course of the 5th century $\mathrm{AD}$, the Roman presence in Belgium came to an effective end. In this period, migration by Germanic groups increased, mainly of Frankish and Saxon origin, in a colonization process starting in the 4th century $\mathrm{AD}$ under Roman occupation. Out of the process of Germanic migration and the mixing with the local Gallo-Roman population, a politically and culturally Merovingian kingdom and culture evolved. At the beginning of the 6th century AD, the Merovingian culture had been shaped and is archaeologically clear to identify. Inhumation was the dominant funerary rite during the Merovingian period in the Austrasian region, which covers eastern France, western Germany, Luxemburg, Belgium, and the Netherlands.

In the Scheldt Valley, however, some cremations are also known, the so-called Brandgrubengräber, which consist of the deposition of a mix of cremated bone and remnants from the pyre in the grave pit. The deposition of specific gendered sets of grave goods for men and women was commonplace in this period. In addition to the single Brandgrubengrab at Borsbeek, other examples of Brand- 


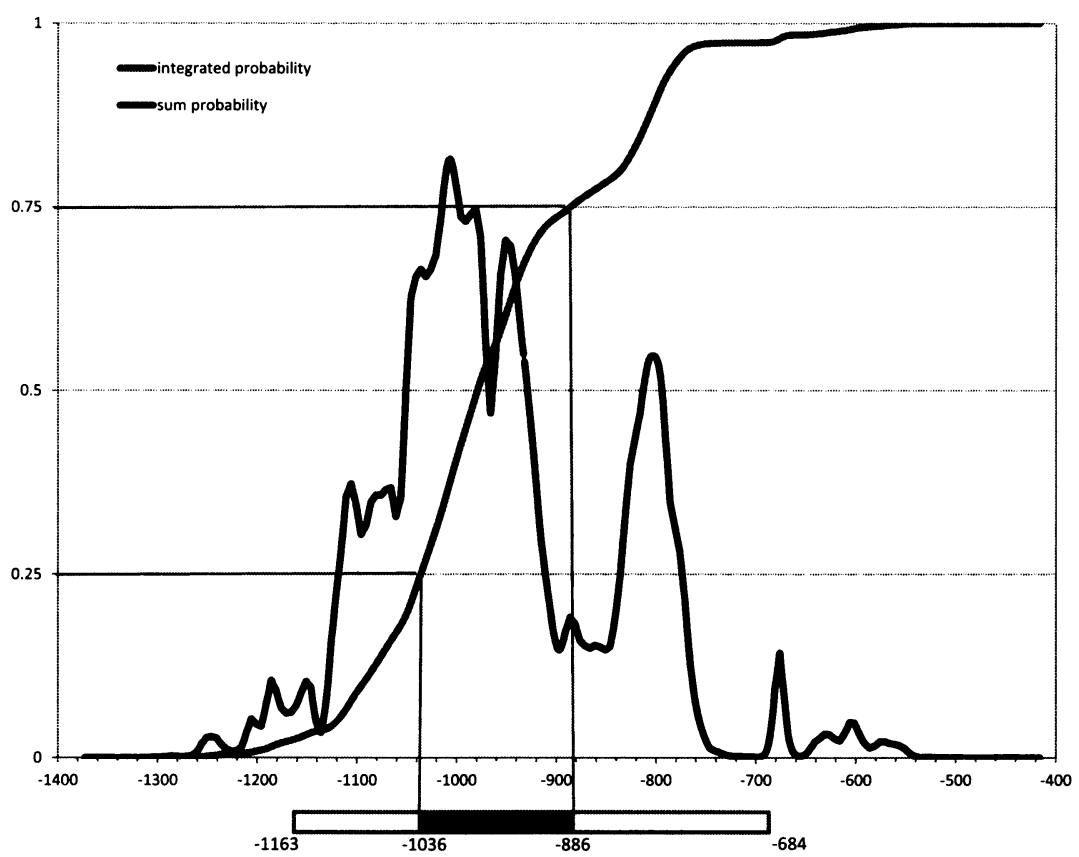

Figure 3 The sum probability of the ${ }^{14} \mathrm{C}$ dates from the Late Bronze Age-Early Iron Age urnfield cemetery.

grubengräber are known from the cemeteries at Dendermonde/Zwijvekekouter (Van Doorselaer 1981; Van Doorselaer and Opsteyn 1981) and Velzeke (Van Doorselaer and Rogge 1985). Three cremated graves at Borsbeek (graves 4, 12, and 14) were unexpectedly dated to the Late RomanMerovingian period within a $2 \sigma$ interval (Figure 4). The ${ }^{14} \mathrm{C}$ dates from Borsbeek showed for the first time that other ways of deposition of cremated bone in this period also existed and that the variety of depositing cremated bone was much larger. Cremation graves 12 and 14 were identified as "bonepackgraves," which are a well-known Bronze Age and Iron Age grave type in the region. The remains were selected from the pyre and wrapped in an organic container, e.g. a piece of cloth or leather, before being buried. This specific way of depositing the cremated remains was until now not recognized in the Merovingian cemeteries of the region. Both bonepackgraves are located in the area were the urnfield cemetery and the Merovingian cemetery overlap each other. It is possible that other undated bonepackgraves in this area are also of early Medieval origin. In a recent excavation from another Merovingian cemetery at Broechem, which is located about $9 \mathrm{~km}$ east from Borsbeek, the findings about the postcremation treatment of the human remains from Borsbeek were confirmed. Most of the cremation graves could be labeled as Brandgrubengräber, but in a specific case a selection of cremated bone has also taken place (Annaert et al. 2010). Cremated bone from 2 Brandgrubengräber has been dated in an interlaboratory comparison. The different results place both graves also in the Merovingian period (Naysmith et al. 2007).

Urngrave 4 is even more enigmatic. Two dates on cremated bone from the same urn also delivered a Merovingian age. The biconical urn and associated cups (Figure 5) were clearly Late Bronze Age according to their typology and fabric. The first idea of a mixing up of cremated bones in a postexcavation situation was discarded because the other urngraves delivered reliable dates. The hypothesis of the deliberate reuse of a Late Bronze Age urn has to be taken into account for 2 reasons. Merovingian cemeteries tend to settle on former Bronze Age funeral sites as is proven by the 


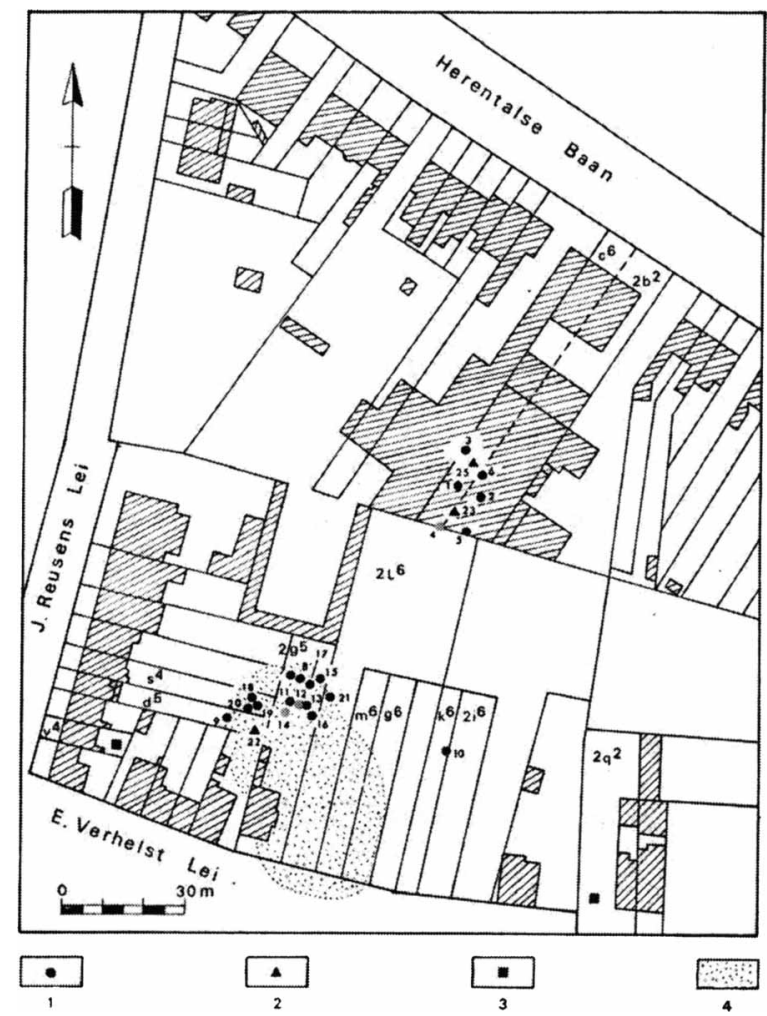

Figure 4 Plan of the urnfield cemetery (1), the Late Iron Age structures (2), and Merovingian cemetery (4). In gray, the $3{ }^{14} \mathrm{C}$-dated Merovingian cremation graves $(4,12$, and 14$)$.

site of Borsbeek itself. Recently, a Merovingian cemetery has been excavated at Beerse/Krommenhof, which reoccupied a Middle Bronze Age barrow funeral site. One of the important Merovingian grave tombs was buried almost in the center of a Bronze Age barrow (Delaruelle and Van Doninck 2009). This practice was already well known from sites in northern France such as Frethun in the Pas-de-Calais (Bostyn et al. 2000) as well as Anglo-Saxon burial sites in southern and eastern England (Williams 1999). The practice of using Roman objects as funerary gifts is also documented in Merovingian cemeteries, and in Ciply (Hainaut) a Late Iron Age urn was probably reused as a funerary commodity (Faider-Feytmans 1970). In Wallin (Luxembourg), a Late Bronze Age urn with cremated bone was found in a Merovingian inhumation cemetery (Leclercq and Pion 2010). Indications of the reuse of Bronze Age barrows and also urns are documented for the Viking period in southwestern Sweden (Magnus Artelius 2010). This information concerning early Medieval funerary practices in reusing cemeteries and material supports the validity of both ${ }^{14} \mathrm{C}$ dates from grave 4 .

Another interesting aspect is the age of the ${ }^{14} \mathrm{C}$ date results versus the typochronology. Based on the typochronology, the cemetery at Borsbeek dates to the late 6 th -7 th century AD. However, the ${ }^{14} \mathrm{C}$ dates suggest that the cemetery started in the 5th-6th century, and so both bonepackgraves are younger than the expected age of the cemetery. The urngrave has a Merovingian age, but is also slightly younger than the typochronological date of the cemetery. This points to an earlier start of the cemetery than archaeologically ascertained by the study of the funerary goods. According to the ${ }^{14} \mathrm{C}$ dates, an early start for these types of burials in the 5th century AD cannot be excluded. Information 


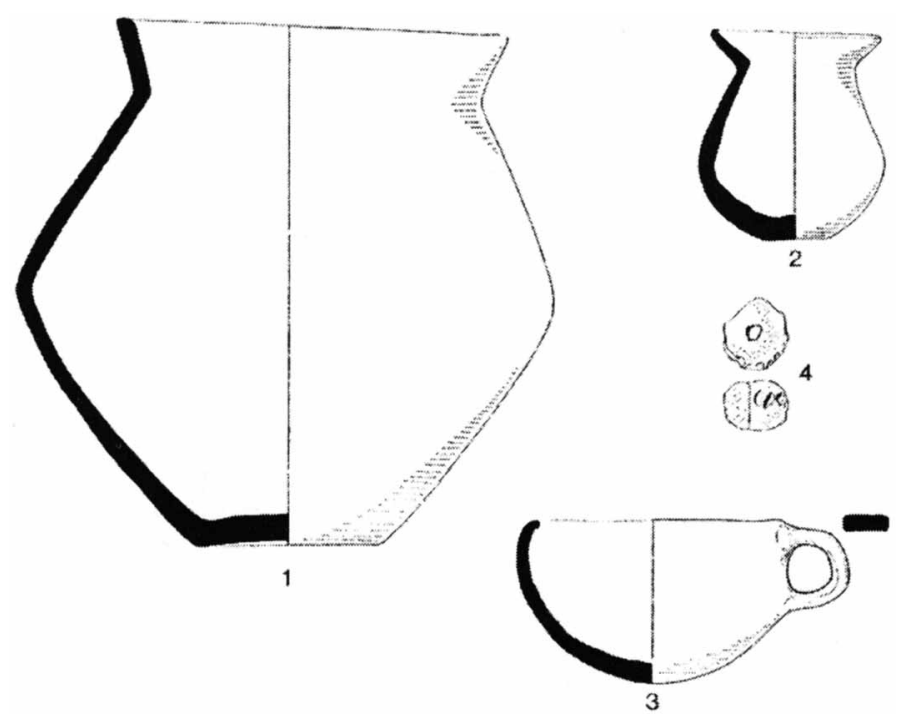

Figure 5 The reused Late Bronze Age urn

about 5th century AD cemeteries is rather scarce in the region. Moreover, at the Broechem burial site cremations were present in the oldest part of the grounds, which seems to have been developed from the middle of the 5th century (Annaert, in press).

Although paleodietary analyses on cremated bones are ineffective (Van Strydonck et al. 2010), a diet-induced ${ }^{14} \mathrm{C}$ offset can be excluded. Iron Age people (Dobney and Ervynck 2007) as well as early Medieval people in Belgium did not consume important amounts of fish (Van Strydonck et al. $2009 \mathrm{~b}$ ). The absence of indications for fish consumption in the archaeological record for both periods confirms the habit of other consumption patterns.

\section{CONCLUSION}

The dating of a Late Bronze Age cemetery delivered some unexpected new insights on the known Merovingian cemetery. The results on 3 cremation graves placed these in the early Medieval period. The bonepackgrave was not ascertained before as a way of deposition of human remains in Merovingian cemeteries. This early Medieval practice of cremation rituals seems to be an of indication of new arrivals of colonists from northern regions where cremation remained the dominant funerary rite. The reuse of a Late Bronze Age urn in the Merovingian period could be attested for the first time in Flanders. This practice is also known from Viking burials in Scandinavia. The ${ }^{14} \mathrm{C}$ dates have also indicated that the cemetery started earlier then the late 6th century AD.

\section{ACKNOWLEDGMENTS}

We wish to thank A Goossens and the board of the local historical and archaeological society Die Swaene at Heist-op-den-Berg for their cooperation in sampling the cremation graves for ${ }^{14} \mathrm{C}$ dating. The province of Antwerp, represented by provincial archaeologist I Bourgeois, supported this project by partially funding the ${ }^{14} \mathrm{C}$ dates. 


\section{REFERENCES}

Annaert R. In press. Who was buried at the Broechem cemetery (5th-7th century AD - B, Antwerp)? In: Annaert R, editor. The Very Beginning of Europe? Cultural and Social Dimensions of Early Medieval Migration and Colonisation (5th-8th century). Proceedings of the ACE-colloquium, 17-19 May 2011, Brussels. Brussels: Relicta. Monografieën.

Annaert R, Deforce K, Vandenbruaene M. 2010. The cremation graves at the Broechem cemetery (prov. of Antwerp, Belgium). In: Ludowici B, Panhuysen T, editors. Transformations in North-Western Europe. Proceedings of the 60th Sachsensymposion, 19-23 September 2009, Maastricht. Hannover: Neue Studien zur Sachsenforschung 3.

Bostyn F, Blancquaert G, Lanchon Y. 2000. Un enclos triple du Bronze ancien à Frethun (Pas-de-Calais). In: Habitats et nécropoles à l'Âge du Bronze sur le Transmanche et le T.G.V. Nord. Paris: Société Préhistorique Française. Travaux 1.p 109-28.

Bronk Ramsey C. 1995. Radiocarbon calibration and analysis of stratigraphy: the OxCal program. Radiocarbon 37(2):425-30.

Bronk Ramsey C. 2001. Development of the radiocarbon calibration program. Radiocarbon 43(2A):355-63.

De Boe G. 1970. Een merovingisch grafveld te Borsbeek (Antwerpen). Brussels: Archaeologia Belgica. 123 p.

Delaruelle S, Van Doninck J. 2009. Uit Kempische bodem. Recent archeologisch onderzoek in de regio Turnhout. AVRA Bulletin 10:4-17.

De Mulder G, Van Strydonck M, Boudin M, Leclercq W, Paridaens N, Warmenbol E. 2007. Re-evaluation of the Late Bronze and Early Iron Age chronology of the western Belgian urnfields based on ${ }^{14} \mathrm{C}$ dating of cremated bones. Radiocarbon 49(2):499-514.

Desittere M, Goossens A. 1966. Twee uitzonderlijke graven van de Urnenveldenkultuur uit Borsbeek (prov. Antwerpen). Helinium 6:218-29.

Dobney K, Ervynck A. 2007. To fish or not to fish? Evidence for the possible avoidance of fish consumption during the Iron Age around the North Sea. In: Haselgrove $\mathrm{C}$, Moore T, editors. The Later Iron Age in Britain and Beyond. Oxford: Oxbow Books. p 403-18.

Faider-Feytmans G. 1970. Les nécropoles mérovingiennes. Morlanwelz: Les collections d'archéologie régionale du Musée de Mariemont, II. $320 \mathrm{p}$.

Lanting JN, van der Plicht J. 2001/2002. De ${ }^{14} \mathrm{C}$-chronologie van de Nederlandse pre- en protohistorie, IV: bronstijd en vroege ijzertijd. Palaeohistoria 43/44: 117-262.

Lanting JN, Aerts-Bijma AT, van der Plicht J. 2001. Dating of cremated bones. Radiocarbon 43(2A):249-54.

Leclercq W, Pion C. 2010. Quand les fossoyeurs du haut Moyen Âge se heurtent à la Protohistoire: sur la découverte de deux tombes de l'âge du Bronze dans le cimetière mérovingien de Wellin (province de Luxembourg, Belgique). Lunula, Archaeologia Protohistorica 17:101-6.
Magnus Artelius T. 2010. Creating a history - Viking Age re-use of Bronze Age barrows in south-western Sweden. In: 16th Annual Meeting. The European Association of Archaeologists, 1-5 September 2010. The Hague, the Netherlands. Leiden. p 58.

Moody G. 2008. The Isle of Thanet from Prehistory to the Norman Conquest. Chalford: Tempus Publishing. $162 \mathrm{p}$.

Naysmith P, Scott EM, Cook GT, Heinemeier J, van der Plicht J, Van Strydonck M, Bronk Ramsey C, Grootes PM, Freeman SPHT. 2007. A cremated bone intercomparison study. Radiocarbon 49(2):403-8.

Reimer PJ, Baillie MGL, Bard E, Bayliss A, Beck JW, Blackwell PG, Bronk Ramsey C, Buck CE, Burr GS, Edwards RL, Friedrich M, Grootes PM, Guilderson TP, Hajdas I, Heaton TJ, Hogg AG, Hughen KA, Kaiser KF, Kromer B, McCormac FG, Manning SW, Reimer RW, Richards DA, Southon JR, Talamo S, Turney CSM, van der Plicht J, Weyhenmeyer CE. 2009. IntCal09 and Marine09 radiocarbon age calibration curves, 0-50,000 years cal BP. Radiocarbon 51(4): 1111-50.

Van Doorselaer A. 1981. De merovingische beschaving in de Scheldevallei. Kortrijk: Westvlaamse Archaeologica Monografieën II.

Van Doorselaer A, Opsteyn L. 1999. Saksische brandrestengraven op de Zwijvekekouter te Dendermonde. Vobov-Info 50:15-22.

Van Doorselaer A, Rogge M. 1985. Continuité d'un rite funéraire spécifique dans la vallée de l'Escaut, de l'âge du fer au haut Moyen Âge (Mélanges d'archéologie nationale offerts au R.P. Wankenne S.J. pour son 75e anniversaire). Les Etudes Classiques LIII(1):153-70.

Van Impe L. 1972. Een urnenveld te Borsbeek. Brussel: Archaeologia Belgica, 140. 37 p.

Van Strydonck M, Boudin M, Hoefkens M, De Mulder G. 2005. ${ }^{14} \mathrm{C}$-dating of cremated bones, why does it work? Lunula, Archaeologia Protohistorica 13:3-10.

Van Strydonck M, Boudin M, De Mulder G. 2009a. ${ }^{14} \mathrm{C}$ dating of cremated bones: the issue of sample contamination. Radiocarbon 51(2):553-68.

Van Strydonck M, Ervynck A, Vandenbruaene A, Boudin M. 2009b. Anthropology and ${ }^{14} \mathrm{C}$ analysis of skeletal remains from relic shrines: an unexpected source of information for Medieval archaeology. Radiocarbon 51(2):569-77.

Van Strydonck M, Boudin M, De Mulder G. 2010. The carbon origin of structural carbonate in bone apatite of cremated bones. Radiocarbon 52(2-3):578-86.

Williams HMR. 1999. Placing the dead: investigating the location of wealthy barrow burials in seventh century England. In: Rundkvist M, editor. Grave Matters. Eight Studies of First Millennium AD Burials in Crimea, England and Southern Scandinavia. BAR International Series 781. Oxford: Archaeopress. p 5786. 